J. Product. \& Dev., 25(4),363-375 (2020)

\title{
THE USE OF COLOSTRUM TO IMPROVE THE FUNCTIONAL AND CHEMICAL PROPERTIES OF ICE CREAM
}

\author{
A. E. Saleh; Moussa, M. A.M.; Hassabo, M. R. and Ewis, A. M.
}

Dairy Res. Dept., Animal Pro. Res. Institute, Agric. Res. Center, Ministry of

Agric., Egypt.Email: Abed.saleh@yahoo.com,mohammedmoussa997@gmail.com

\begin{abstract}
Ice cream is made using different proportions of colostrum. The physical chemical activity, rheology, antioxidant scavenging and organoleptic properties of colostrum-fortified ice cream were studied.

From the results obtained, it was found that there was an increase in the content of protein, carbohydrates and antioxidants by adding colostrum during the manufacture of ice cream and the $T_{3}$ score was higher (30\% colostrum) than control. The chemical composition of the produced ice cream indicates excess fat, ash, TS and mineral contents; there was also an increase in the viscosity and antioxidant activity by increasing the added colostrum. On the other hand, all types of ice cream showed a decrease in mating rate. Tissue properties (TPA) are improved by increasing the amount of added colostrum.
\end{abstract}

Conclusively, there was improvement in nutritional and sensory properties by adding colostrum.

Key words: Ice cream, colostrum, physic-chemical, antioxidant activity and sensory quality.

\section{INTRODUCTION}

Ice cream is a sweetened frozen food mostly eaten as a snack or dessert. It is usually made up of dairy products, such as milk and milk cream and also often combined with fruits or other ingredients for flavor and as well as color. It is typically sweetened with sugar or sugar alternatives. Flavorings and colorings are added in combination to stabilizers and emulsifiers. For ice cream preparation, the prepared ice cream mixture is agitated to incorporate void or air spaces and cooled down rapidly below the freezing point of water to prepare ice cream of desired characteristics (Kailasapathy and Sultana, 2003).

As a result, produced ice cream would have smooth, semi-solid foam which is solid at low temperature. It becomes softer again as the temperature increases. Nutritional and physico-chemical properties are important deciding factor when consumers purchase any dairy products. Earlier ice cream was 
considered a food for enjoyment, rather than a basic food. Driven by increasing incomes and health consciousness among the consumers, value addition to dairy products has witnessed a significant increase over the past few years. Fortify ice cream with nutrients or other bioactive substances such as colostrum, led to improve quality and physical-chemical properties of ice cream (Anal and Singh, 2007).

Ice cream can be considered as an aerated suspension of crystallized fat and water in a highly concentrated sugar solution containing hydrocolloids, casein micelles, and proteins Eisner et al. (2005). The texture of the ice cream depends on many factors such as the state of aggregation of the fat globules, the amount of air, the size of the air cells, the viscosity of the aqueous phase, and the size and state of aggregation of ice crystals (Aime et al., 2001).The energy value of the products from which it is made. Ice cream also contains high levels of milk fat, $10-16 \%$ and is a source of high quality protein and energy. Ice cream plays an important role of actual food which, besides its digestive and metabolic qualities, has nutritive qualities, but can also influence the mind because of its organoleptic characteristics and its importance as thermoregulatory food in the fight against heat (Del Giovine and Piccioli, 2003). Several studies of pediatrics recognize that ice cream plays a fundamental role in children's diets, who consume great amounts of it. But the presence of additives, particularly of dyes, can introduce a risk factor. Therefore, the use of natural additives to ice cream has an important concept (Del Giovine and Piccioli, 2003).

Colostrum is considered as a vital food for the newborn of all mammals in the first day after birth. Colostrum contains various nutrients including protein, fat, carbohydrate, water, fat-soluble vitamins and minerals as well as many biologically active substances such as immunoglobulins, antimicrobial factors, growth factors and others (Gauthier et al., 2006). The most important bioactive components in colostrum improved growth and developments of the newborn while antimicrobial factor provide passive immunity and protect against infections during the first weeks of life. The antimicrobial activity of colostrum is due mostly to immunoglobulins, although colostrum also contains other antimicrobial factors, lactoferrin, lysozyme and lactoperoxidase (Gauthier et al., 2006).

In general, colostrum contains less lactose and more fat, protein, peptides, non-protein nitrogen, ash, vitamins and minerals, hormones, growth factors, cytokines and nucleotides than mature milk; except in the case of lactose, the levels of these compounds decrease rapidly during the first 3 days of lactation (Uruakpa et al., 2002). Colostrum is characterised by its very high 
concentration of immunoglobulin which is of particular importance to the neonate, whose gut, immediately following parturition, allows the passage of large immunoglobulins, thereby conferring passive immunity (Stelwagen et al., 2009). It is essential that the newborn calf receives an adequate supply of colostrum as the concentration of immune-globulins and permeability of the gut decrease rapidly over the first $24 \mathrm{~h}$ following parturition (Moore et al., 2005). In addition, colostrum intake influences metabolism, endocrine systems and the nutritional and stimulates the development and function of the gastrointestinal tract but, typically, milk collected during the colostrum period is considered unmarketable and often is excluded from bulk milk collection Marnila and Korohnen (2002). The high protein content of colostrum leads to multiple problems in industrial processes, e.g. poor heat stability, which interferes with pasteurization (McMartin et al., 2006). Also, the high content of antimicrobial components in colostrum may affect the fermentation process. Despite this, colostrum has attracted considerable interest as a functional food ingredient (Korohnen, 1998).

Consumption of dairy products is associated with beneficial health effects beyond their nutritional values. The healthy perception, dairy products have been served as vehicles for functional food ingredients over the last 25 years. Due to the bioactive components in the colostrum such as immunoglobulins, antimicrobial such as lactoferrin, lysozyme and lactoperoxidase growth factors and others.

Therefore, the objective of the present study was to investigate the effect of addition of colostrum to increase antioxidant properties of ice cream and to determine the potential use of colostrum as a healthy ingredient in ice cream. Also, to evaluate the effects of adding colostrum on the functional and organoleptic properties of ice cream.

\section{MATERIALS AND METHODS}

\section{MATERIALS}

Fresh buffalo milk (6\% fat) and buffalo colostrum used in this study was obtained from the dairy farm at the Animal Production Research Station, Mahatta Moses, Kafr El-Sheikh, Agricultural Research Center, Ministry of Agriculture, Egypt.

\section{Treatments:}

The contents of components used in ice cream mix formulations (percentage by weight) are shown in (Table1) 
Table (1): The content of components used in ice cream mix formulations (percentage by weight)*.

\begin{tabular}{|c|c|c|c|c|c|c|c|}
\hline \multicolumn{9}{|c|}{ Sample } & $\begin{array}{c}\text { buffalos } \\
\text { milk } \\
\mathbf{( k g )}\end{array}$ & $\begin{array}{c}\text { buffalos } \\
\text { colostrum } \\
(\mathbf{k g})\end{array}$ & $\begin{array}{c}\text { Butter } \\
(\mathbf{8 5 \%} \\
(\mathbf{g m})\end{array}$ & $\begin{array}{c}\text { Skim } \\
\text { milk } \\
\text { powder } \\
(\mathbf{g m})\end{array}$ & $\begin{array}{c}\text { Sugar } \\
\mathbf{( 1 0 \% )} \\
\mathbf{( g m )}\end{array}$ & $\begin{array}{c}\text { Stabilizer } \\
\mathbf{( 0 . 5 \% )} \\
(\mathbf{g m})\end{array}$ & $\begin{array}{c}\text { Vanillin } \\
(\mathbf{0 . 1 \%}) \\
(\mathbf{g m})\end{array}$ \\
\hline Control & 4 & - & 305 & 105 & 750 & 25 & 5 \\
\hline T1 & 3.600 & 0.400 & 295 & 85 & 750 & 25 & 5 \\
\hline T2 & 3.200 & 0.800 & 280 & 63 & 750 & 25 & 5 \\
\hline T3 & 2.800 & 1.200 & 266 & 42 & 750 & 25 & 5 \\
\hline T4 & 2.400 & 1.600 & 253 & 21 & 750 & 25 & 5 \\
\hline
\end{tabular}

*5 kg mixture.

\section{METHODS:}

\section{Manufacture of Ice cream:}

The ice cream mixture was prepared using different formulations of full cream buffalo milk ( $6 \%$ fat) with four levels of buffalo colostrum. Ice cream was prepared according to (Marshall and Arbuckle, 1996). The basic ice cream mixture has been standardized to contain $10 \%$ fat, $10 \%$ non-fat solid milk (MSNF), $15 \%$ sugar (66\% sucrose $+33 \%$ glucose), and $0.5 \%$ gelatin as a stabilizer. The required quantities of sugar, stabilizer, skimmed milk powder (97\% DM), butter ( $85 \%$ fat), and whole buffalo milk ( $6 \%$ fat) were calculated.

The mixture was divided into five equal parts, $0.1 \%$ vanilla was added to the part, while the other parts $\left(\mathrm{T}_{1}, \mathrm{~T}_{2}, \mathrm{~T}_{3}, \mathrm{~T}_{4}\right)$ were enriched with colostrum at a concentration of $10,20,30$ and $40 \%$, respectively. This concentration was added to ice cream mixes according to the levels used. The mixture was heated at $85{ }^{\circ} \mathrm{C}$ for 5 minutes, then cooled to $5{ }^{\circ} \mathrm{C}$ and kept at the same temperature ( 5 ${ }^{\circ} \mathrm{C}$ ) overnight for aging. After aging the ice cream maker (Taylormate TM Model 152, Taylor Company, Blackhawk Blvd, USA) was whipped. Ice cream was collected at an exit temperature of $-5.5^{\circ} \mathrm{C}$ and placed in $100 \mathrm{~mL}$ plastic cups, covered and stored at $-18{ }^{\circ} \mathrm{C}$ until analysis. All ice cream treatments were prepared in three replications.

\section{Chemical and physical properties:}

The ice cream samples were analyzed triplicates. Total solids, protein, fat, titratable acidity, ash, $\mathrm{pH}$ value and carbohydrate contents were determined according to the (AOAC, 2007). The antioxidant activity DPPH Assay (2, 2Dipheny1-1-picrylhydrazyl) was determined by the method described by (Blois, 1958). Mineral content $\mathrm{Ca}, \mathrm{Na}, \mathrm{K}, \mathrm{Mg}, \mathrm{Fe}$ and $\mathrm{Zn}$ were determined 
according to the method of James (1995). Ice cream mixes were analyzed for specific gravity, weight per gallon of ice cream mix in kilograms and freezing point (Arbuckle 1986). Viscosity measurements of the molten ice cream were taken at $10{ }^{\circ} \mathrm{C}$ with a Brokfield viscometer (Model DV-1+, Brookfield Engineering Laboratories, Inc., Middleboro, USA). The viscometer was operated at $30 \mathrm{rpm}$ (spindle number 4). Each result in triplicate was recorded in $\mathrm{cP}$ at 30s rotation (Akbulut and Coklar, 2008).

The overrun was measured as described by (Marshall and Arbuckle 1996). Meltdown rates of the ice cream samples were measured in a controlled temperature chamber $\left(23 \pm 2{ }^{\circ} \mathrm{C}\right)$. The ice cream samples were stored at $-25{ }^{\circ} \mathrm{C}$ before carrying out the melting test. For melt-down rate $75 \mathrm{~g}$ of ice cream were placed on a stainless steel screen (mesh size $2.5 \mathrm{~mm}$ ) under which a measuring cylinder was put for the melted ice cream collection. The timing of the meltdown rate began when the first drop of the melt after 19-23 s touched the bottom of the cylinder. The weight of the material passing through the screen was recorded every $15 \mathrm{~min}$ for $75 \mathrm{~min}$ (Bollinger et al., 2000).

\section{Sensory analysis:}

The sensory attributes of fresh ice cream from different treatments were assessed by 10 panelists of Department of dairy science Animal Production Research Institute, Agricultural Research Center, Ministry of Agriculture. The samples stored at $-18^{\circ} \mathrm{C}$ were tempered at room temperature for 10 min prior to sensory testing. Scoring was carried out according to Gafour et al. (2007) for flavour (50 points), body and texture (30 points), melting properties (10 points) and colour (10 points).

\section{Statistical analysis:}

All measurements were done in triplicates, and analysis of variance with one factorial (treatments) were conducted by the procedure of General Linear Model ( GLM) according to (Snedcor and Cochran, 1967) using Costat under windows software version 6.311 and least significant difference (LSD) test were employed to determine significant difference at $\mathrm{P}<0.01$.

\section{RESULTS AND DISCUSSION}

Table (2) illustrate the physical chemical properties of fresh buffaloes milk and buffaloes colostrum used for preparation of ice cream including fat, protein, total solids, ash, lactose, acidity, $\mathrm{pH}$, specific gravity, DPPH inhibition, $\operatorname{lgG}, \operatorname{lgM}$, lactoferrin, vitamin $\mathrm{A}$, vitamin $\mathrm{E}$, and mineral contents. According to the obtained data it could be conclude that all the components of buffalo's colostrum were higher than that of buffalo's milk 
Table (2): Physico- chemical composition of buffalo's milk and buffalo's colostrum used in preparation of ice cream*.

\begin{tabular}{|l|c|c|}
\hline \multicolumn{1}{|c|}{ Components } & Buffaloes milk & Buffaloes colostrum \\
\hline Total solids \% & 16.80 & 24.00 \\
\hline Fat \% & 6.00 & 8.80 \\
\hline Protein \% & 4.35 & 10.20 \\
\hline Lactose \% & 5.50 & 3.80 \\
\hline Ash \% & 0.75 & 1.20 \\
\hline Acidity \% & 0.16 & 0.25 \\
\hline $\mathrm{pH}$ & 6.63 & 6.32 \\
\hline Specific gravity & 1.034 & 1.062 \\
\hline DPPH inhibition**\% & 7.89 & 12.30 \\
\hline IgG** mg/ml & 11.44 & 25.00 \\
\hline IgM*** mg/ml & 2.10 & 1.80 \\
\hline Lactoferrin mg/ml & 0.20 & 1.20 \\
\hline Vitamin A IU/100ml & 102.00 & 188.30 \\
\hline Vitamin E IU/100ml & 190.40 & 396.55 \\
\hline Ca mg/100ml & 129.00 & 284.80 \\
\hline Na mg/100ml & 133.00 & 105.80 \\
\hline $\mathrm{K} \mathrm{mg/100ml}$ & 42.00 & 102.20 \\
\hline $\mathrm{Mg} \mathrm{mg} / 100 \mathrm{ml}$ & 9.70 & 29.20 \\
\hline Zn mg/100ml & 2.80 & 0.20 \\
\hline Fe mg/100ml & 0.30 & 0.78 \\
\hline
\end{tabular}

*C. F. Saleh et al., (2019).

**DPPH inhibition: 2, 2-Diphenyl-1-picrylhydrazyl (DPPH) inhibition (\%)

***IgG: Immunoglogulin $\mathrm{G}$ (IgG)

****IgM: immunoglobulins termed $\operatorname{IgM}$

except the value of lactose which recorded 5.50\% for buffalo's milk. These results are in accordance with (Vincu et al. 2005) who reported that colostrum is very rich in minerals, proteins and immunoglobulin but has less lactose compared to the whole milk.

Results presented in Table (3) shows the chemical composition of ice cream that was prepared with buffalo's colostrum. Addition of 10, 20, 30 and $40 \%$ buffalos colostrum significantly increased the total solids (TS), fat, protein, ash and carbohydrate contents of ice cream compared with the control. Total solids (TS) content was significantly affected by adding buffalo's colostrum. The recorded value in ice cream (36.29\%) was significantly higher $(\mathrm{P}<0.01)$ in treatment $\mathrm{T} 4$ compared to the control, $\mathrm{T}_{1}$, $\mathrm{T}_{2}$ and $\mathrm{T}_{3}(34.20,35.56,35.90$ and $36.12 \%$ respectively). Fat content in ice cream was found to be slightly or not affected by adding buffalo's 
Table (3): Effect of using different ratios of buffalo's colostrum on the chemical properties of the resultant ice cream (average of three replicates).

\begin{tabular}{|l|c|c|c|c|c|}
\hline \multirow{2}{*}{ Property } & \multicolumn{5}{|c|}{ Treatments $^{*}$} \\
\cline { 2 - 6 } & Control & $\mathbf{T}_{\mathbf{1}}$ & $\mathbf{T}_{\mathbf{2}}$ & $\mathbf{T}_{\mathbf{3}}$ & $\mathbf{T}_{\mathbf{4}}$ \\
\hline TS \% & $34.20^{\mathrm{d}}$ & $35.56^{\mathrm{c}}$ & $35.90^{\mathrm{b}}$ & $36.12^{\mathrm{ab}}$ & $36.29^{\mathrm{a}}$ \\
\hline Fat \% & $10.00^{\mathrm{d}}$ & $10.20^{\mathrm{c}}$ & $10.26^{\mathrm{c}}$ & $10.40^{\mathrm{b}}$ & $10.56^{\mathrm{a}}$ \\
\hline Protein \% & $4.90^{\mathrm{c}}$ & $4.95^{\mathrm{c}}$ & $5.10^{\mathrm{b}}$ & $5.18^{\mathrm{b}}$ & $5.37^{\mathrm{a}}$ \\
\hline Acidity \% & $0.22^{\mathrm{e}}$ & $0.24^{\mathrm{d}}$ & $0.28^{\mathrm{c}}$ & $0.31^{\mathrm{b}}$ & $0.36^{\mathrm{a}}$ \\
\hline $\mathrm{pH}$ & $6.49^{\mathrm{a}}$ & $6.41^{\mathrm{b}}$ & $6.38^{\mathrm{c}}$ & $6.34^{\mathrm{d}}$ & $6.32^{\mathrm{d}}$ \\
\hline Ash \% & $0.88^{\mathrm{d}}$ & $0.90^{\mathrm{c}}$ & $1.07^{\mathrm{b}}$ & $1.08^{\mathrm{b}}$ & $1.09^{\mathrm{a}}$ \\
\hline Carbohydrate\% & $4.92^{\mathrm{d}}$ & $5.59^{\mathrm{d}}$ & $5.63^{\mathrm{c}}$ & $5.75^{\mathrm{b}}$ & $5.98^{\mathrm{a}}$ \\
\hline $\begin{array}{l}\text { Antioxidant } \\
\text { activity DPPH (\%) }\end{array}$ & $12.24^{\mathrm{e}}$ & $14.50^{\mathrm{d}}$ & $15.35^{\mathrm{c}}$ & $18.20^{\mathrm{b}}$ & $19.55^{\mathrm{a}}$ \\
\hline
\end{tabular}

$\mathrm{a}, \mathrm{b}, \mathrm{c} . .$. Means with the same column with different superscript are significantly different $(\mathrm{P}<0.01)$.

*See legend to Table (1) for details

colostrum, as shown in Table (3). The highest value was recorded in the ice cream made from treatment $\mathrm{T}_{4}(10.56 \%)$, followed by those from $\mathrm{T}_{3}$ $(10.40 \%), \mathrm{T} 2(10.26 \%), \mathrm{T}_{1}(10.20 \%)$ and control (10\%) respectively. This attributes to the higher percentage of milk proteins especially whey proteins in colostrum (Table 2).

Concerning protein content, the recorded average values of ice cream were the lowest $(\mathrm{P}<0.01)$ in the control compared with treatments $\mathrm{T}_{1}, \mathrm{~T}_{2}$, $\mathrm{T}_{3}$ and $\mathrm{T}_{4}$. However, the protein content gradually increased in all treatments with an increase in the added percentage of buffalo's colostrum. The measured average values were 4.90, 4.95, 5.10, 5.18 and $5.37 \%$ for control, $\mathrm{T}_{1}, \mathrm{~T}_{2}, \mathrm{~T}_{3}$ and $\mathrm{T}_{4}$ respectively.

Table (3) showed that the acidity, $\mathrm{pH}$ values, ash, carbohydrates and total antioxidant activity of ice cream without colostrum compared to ice cream with colostrum samples had slightly higher acidity than control. Also, due to the presence of bioactive ingredients in colostrum and its effective use (Tripathi and Vashishtha, 2006). The $\mathrm{pH}$ values of all the produced ice cream took an opposite trend to that of the acidity. The obtained results also revealed the increase of ash contents of ice cream contained colostrum than the control samples. The increase was also proportional to the increase of colostrum added. This could be due to that colostrum had high total solids as compared to normal milk (Poonia and Dabur, 2015). 
The results in Table (3) showed the effectiveness of buffalo colostrum used in making ice cream in its carbohydrates and antioxidant content. The results obtained indicated that the control ice cream had the lowest carbohydrate content. But the results obtained showed that ice cream made with different proportions of buffalo colostrum had the highest antioxidant activity. The samples recorded 12.24, 14.50, 15.35, 18.20 and $19.55 \%$ inhibition of DPPH for control, $\mathrm{T}_{1}, \mathrm{~T}_{2}, \mathrm{~T}_{3}$ and $\mathrm{T}_{4}$ respectively. In general, fortification of ice cream with colostrum increased antioxidant activity and this increase in parallel with the proportion of added colostrum.

The physical properties of ice cream are presented Table (4). The physical properties of ice cream are presented Table (3). Results showed that all ice cream samples had higher values for specific gravity than the control one. This may be due to the high solids not fat contents as compared to control one. Adding buffalo's colostrum increases significantly $(\mathrm{P}<0.01)$ specific gravity values and these increases were proportional to the added colostrum ratio. The specific gravity of buffalo's colostrum was found to be 1.062 which explains the increase in the specific gravity on its addition to ice cream. Additionally, control tends to have a higher rate of bypass \% than treatments with colostrum. This may be due to the high contribution of fat to the stability of air phase of ice cream during freezing and whipping (Goff et al., 1999). The control showed a significant increase $(\mathrm{P}<0.01)$ in the ice cream overrun for the treatments, which could be attributed to the increase in the viscosity of the mixture that did not contain colostrum (Table 4). The increases in overrun are parallel to the increase for viscosity values.

The low freezing point is an important parameter in ice cream production because it affects the initial average size and thermodynamic instability of the ice crystals formed resulting in their growth (Hartel, 2001). The freezing point (Table 4) of the control ice cream was $-2.40^{\circ} \mathrm{C}$ which is close to that found by (Cogne et al., 2003). Statistical analysis showed significant difference $\mathrm{i}$ freezing point $\mathrm{T}_{1}, \mathrm{~T}_{2}, \mathrm{~T}_{3}$ and $\mathrm{T}_{4}$ which can be attributed to the differences in total solids and fat contents.

Table (4) shows that the ice cream with colostrum added that took longer time to melt than the ice cream without colostrum. They indicate that milk fat improved the melting resistance of ice cream. The contribution of fat to the structural characteristics properties of ice cream and reduced heat conductivity can explain the former effects (Soukoulis et al., 2010). Addition of colostrum slightly improved the melting resistance of the ice cream samples. 
Table (4): Effect of using different ratios of buffalo's colostrum on the physical properties of the resultant ice cream (average of three replicates).

\begin{tabular}{|l|c|c|c|c|c|}
\hline \multirow{2}{*}{ Property } & \multicolumn{5}{|c|}{ Treatments $^{*}$} \\
\cline { 2 - 6 } & Control & $\mathbf{T}_{\mathbf{1}}$ & $\mathbf{T}_{\mathbf{2}}$ & $\mathbf{T}_{\mathbf{3}}$ & $\mathbf{T}_{\mathbf{4}}$ \\
\hline Specific gravity & $1.0352^{\mathrm{d}}$ & $1.0385^{\mathrm{c}}$ & $1.0426^{\mathrm{b}}$ & $1.0485^{\mathrm{b}}$ & $1.0549^{\mathrm{a}}$ \\
\hline Overrun \% & $30.00^{\mathrm{ab}}$ & $26.00^{\mathrm{bc}}$ & $21.65^{\mathrm{d}}$ & $20.33^{\mathrm{d}}$ & $19.00^{\mathrm{d}}$ \\
\hline Viscosity (cp) & $2.49^{\mathrm{a}}$ & $2.29^{\mathrm{d}}$ & $2.24^{\mathrm{d}}$ & $2.32^{\mathrm{c}}$ & $2.40^{\mathrm{b}}$ \\
\hline freezing point $\left({ }^{\mathrm{C}} \mathrm{C}\right)$ & $-2.40^{\mathrm{a}}$ & $-2.49^{\mathrm{a}}$ & $-2.58^{\mathrm{b}}$ & $-2.60^{\mathrm{c}}$ & $-2.64^{\mathrm{c}}$ \\
\hline $\begin{array}{l}\text { Meltdown rates }(\%) \\
\text { after } 15 \text { min at } 25^{\circ} \mathrm{C}\end{array}$ & $75.53^{\mathrm{d}}$ & $75.96^{\mathrm{d}}$ & $76.42^{\mathrm{c}}$ & $77.10^{\mathrm{b}}$ & $78.32^{\mathrm{a}}$ \\
\hline
\end{tabular}

$\mathrm{a}, \mathrm{b}, \mathrm{c} . .$. Means with the same column with different superscript are significantly different $(\mathrm{P}<0.01)$.

*See legend to Table (1) for details

Table (5) showed that the mineral contents (mg/100gm) of ice cream with buffalo's colostrum. The results of mineral analysis revealed that the $\mathrm{Ca}, \mathrm{Mg}, \mathrm{Na}, \mathrm{Fe}, \mathrm{K}$ and $\mathrm{Zn}$ contents of ice cream with buffalo's colostrum had higher values compared to control ice cream samples and this was proportional to the amount of colostrum added. This also, due to the higher contents of colostrum for minerals. These results are in agreement with (Saleh et al., 2019), who found that the use of colostrum in the manufacture of stirred yoghurt increases the mineral content.

Table (5): Effect of using different ratios of buffalo's colostrum on the minerals contents $(\mathrm{mg} / 100 \mathrm{gm})$ of the resultant ice cream (average of three replicates).

\begin{tabular}{|c|c|c|c|c|c|}
\hline \multirow{2}{*}{ Property } & \multicolumn{5}{|c|}{ Treatments* $^{*}$} \\
\cline { 2 - 6 } & Control & $\mathbf{T}_{\mathbf{1}}$ & $\mathbf{T}_{\mathbf{2}}$ & $\mathbf{T}_{\mathbf{3}}$ & $\mathbf{T}_{\mathbf{4}}$ \\
\hline $\mathrm{Ca}$ & $125.90^{\mathrm{e}}$ & $160.10^{\mathrm{d}}$ & $185.50^{\mathrm{c}}$ & $225.00^{\mathrm{b}}$ & $286.20^{\mathrm{a}}$ \\
\hline $\mathrm{Mg}$ & $10.50^{\mathrm{e}}$ & $11.50^{\mathrm{d}}$ & $13.20^{\mathrm{c}}$ & $15.75^{\mathrm{b}}$ & $17.98^{\mathrm{a}}$ \\
\hline $\mathrm{Na}$ & $35.50^{\mathrm{e}}$ & $40.30^{\mathrm{d}}$ & $42.65^{\mathrm{c}}$ & $45.90^{\mathrm{b}}$ & $49.25^{\mathrm{a}}$ \\
\hline $\mathrm{Fe}$ & $0.33^{\mathrm{d}}$ & $0.45^{\mathrm{c}}$ & $0.69^{\mathrm{b}}$ & $0.70^{\mathrm{b}}$ & $0.95^{\mathrm{a}}$ \\
\hline $\mathrm{K}$ & $71.92^{\mathrm{e}}$ & $75.90^{\mathrm{d}}$ & $80.00^{\mathrm{c}}$ & $81.20^{\mathrm{b}}$ & $98.59^{\mathrm{a}}$ \\
\hline $\mathrm{Z}$ & $2.25^{\mathrm{e}}$ & $3.80^{\mathrm{d}}$ & $4.20^{\mathrm{c}}$ & $5.80^{\mathrm{b}}$ & $7.93^{\mathrm{a}}$ \\
\hline
\end{tabular}

$\mathrm{a}, \mathrm{b}, \mathrm{c} . .$. Means with the same column with different superscript are significantly different $(\mathrm{P}<0.01)$.

*See legend to Table (1) for details

Table (6) shows the scores for sensory properties of the ice cream produced by adding different proportions of buffalo's colostrum. The 
Table (6): Effect of using different ratios of buffalo's colostrum on the sensory evaluation of the resultant ice cream (average of three replicates).

\begin{tabular}{|l|c|c|c|c|c|}
\hline \multicolumn{1}{|c|}{ Property } & Control & $* \mathbf{T}_{\mathbf{1}}$ & $\mathbf{T}_{\mathbf{2}}$ & $\mathbf{T}_{\mathbf{3}}$ & $\mathbf{T}_{\mathbf{4}}$ \\
\hline $\begin{array}{l}\text { Flavour } \\
\text { (50points) }\end{array}$ & 48.50 & 48.00 & 48.00 & 48.50 & 47.00 \\
\hline $\begin{array}{l}\text { Body \&Texture } \\
\text { (50 points) }\end{array}$ & 28.00 & 28.00 & 28.00 & 28.50 & 27.00 \\
\hline $\begin{array}{l}\text { Melting properties } \\
(10 \text { points) }\end{array}$ & 9.50 & 9.00 & 9.50 & 10.00 & 9.00 \\
\hline $\begin{array}{l}\text { Colour } \\
(10 \text { points) }\end{array}$ & 10.00 & 9.00 & 9.50 & 9.50 & 9.00 \\
\hline Total cceptability & $96.00^{\mathrm{a}}$ & $94.00^{\mathrm{b}}$ & $95.00^{\mathrm{ab}}$ & $96.50^{\mathrm{a}}$ & $92.00^{\mathrm{c}}$ \\
\hline
\end{tabular}

$a, b, c . .$. Means with the same column with different superscript are significantly different $(\mathrm{P}<0.01)$.

*See legend to Table (1) for details

creamy ice cream resulting from the control and coefficients $T_{1}, T_{2}$ and $T_{3}$ was distinguished by the creamy taste and obtained the highest degrees of sensory evaluation of the flavor, while $\mathrm{T}_{4}$ got a lower score. Milk fat has been recognized as a critical parameter for the formation and support of the structural properties of ice cream (Turgut and Cakmacki 2009). The results showed that adding buffalo's colostrum to the ice cream mixture up to $30 \%$ led to a significant improvement in the body \& texture, melting properties and colour of the resulting ice cream samples and gained acceptance scores such as control. Generally, $\mathrm{T}_{3}$ and $\mathrm{T}_{2}$ have a similar degree of control, but $\mathrm{T}_{1}$ and $\mathrm{T}_{4}$ had a lower degree of control.

Conclusively, addition of colostrum to enrich antioxidant properties of ice cream was investigated. Functional and organoleptic properties of enriched ice cream with colostrum were also evaluated. It could be concluded that, colostrum was effective regarding antioxidant activity.

Therefore, it could be used as good source of antioxidants for making ice cream with good nutritional and functional properties. Also, the obtained results suggest that, ice cream can be successfully mad using colostrum for improving the nutritional and sensorial qualities and physic-chemical characteristics of ice cream. Also, the produced ice cream with colostrum had had antioxidant activity better than the control ice cream throughout storage at $-18 \mathrm{C}^{0}$. Colostrum can be used in the manufacture ice cream up to 30 or $40 \%$. 


\section{REFERENCES}

Anal, AK. And Singh, H. (2007). Recent advances in microencapsulation of probiotics for industrial applications and targeted delivery. Trends Food Sci. Tech. 18: 240- 251.

Aime D., Arntfield S. D., Malcolmson L. J. and Ryland D. (2001). Textural analysis of fat reduced vanilla ice cream products. Food Research International, 34: 237- 246.

Akbulut, M. and Coklar, H. (2008). Physicochemical and Rheological properties of sesame pastes processed from hulled and unhulled roasted sesame seeds and their blends at various levels. Journal of Food Process Engineering, 31: 488- 502.

A.O.A.C (2007). Official Methods of Analysis, 18th ed. Association of Official Analytical Chemists, Gaithersburg, MD, USA.

Arbuckle, W. S. (1986). Ice cream. 3 rd. edition AVI publishing Co., Westport Connecticut, USA.

Blois, M.S. (1958). Antioxidant determinations by the use of a stable free radical. Nature, 181: 1199-1200.

Bolliger, S., Goff, H. D. and Tharp, B. W. (2000). Correlation between colloidal properties of ice cream mix and ice cream. International Dairy Journal, 10: 303-309.

Cogne, C.; Andrieu, J.; Laurent, P.; Besson, A. and Nocquet, J. (2003). Experimental data and modeling of thermal properties of ice cream. Journal of Food Eng., 58: 331.

Del Giovine, L. and Piccioli, A. (2003). Determination of synthetic dyes in ice cream by capillary electrophoresis. Food Control, 14: 131-135.

Eisner, M. D., Wildmoser, H. and Windhab, E. (2005). Air cell microstructuring in a high viscous ice cream matrix. Colloids and Surfaces A, 263: 390- 399.

Gafour, W. A; Essawy, E. A. Y, and Salem, A. S. (2007). Incorporation of natural antioxidants into ice cream. Egyptian J. Dairy Sci., 35:117.

Gauthier, S.F.; Pouliot, Y. and Maubois, J .L. (2006). Growth factors from bovine milk and colostrum: composition, extraction and biological activities. Lait., 86: 99-125.

Goff, H. D.; Verespej, E. and Smith, A. K. (1999). A study of fat and air structures in ice cream. Int. Dairy J., 9: 817.

Hartel, R. W. (2001). Crystallization in Foods. $\left(1^{\text {st }}\right)$ ed. Gaithersburg, Maryland: Aspen Publishers Inc.,USA 
James, C.S. (1995) Analytical Chemistry of Food. Blackie Academic and Professionals, London, 256-257.

Kailasapathy, K. and Sultana, K. (2003). Survival and b-D- galactosidase activity of encapsulated and free Lactobacillus Acidophilus and bifidobacterium lactis in ice cream. Aust. J. Dairy Tech., 58 (3): 223227.

Korohnen, H. (1998). Colostrum immunoglobulins and the complement system potential ingredients of functional foods. Bulletin 336, Inter. Dairy Federation, Brussels, pp. 36-40.

Marnila, P. and Korhonen, H. (2002). Colostrum. In: Encyclopedia of Dairy Sci. Academic Press, London. 473-478.

Marshall, R. T. and Arbuckle W. S. (1996). The polyphenol constituents of grape pomace. Food Chemistry, 65, 1-8.

McMartin, S.; Godden, S. M.; Metzger, L.; Feirtag, J.; R. Bey, R.; Stabel, Goyal, S.; Fetrow, J.; Wells, S. and Chester, J. H. (2006). Heat treatment of bovine colostrum I. Effects of temperature on viscosity and immunoglobulin G level. J Dairy Sci., 89:2110-2118.

Moore, M.; Tyler, J. W.; Chigerwe, M.; Dawes, M. E. and Middleton, J. R. (2005). Effect of delayed colostrum collection on colostral IgG concentration in dairy cows. J. Am. Vet. Med. Assoc., 226:1375-1377.

Poonia, A. and Dabur, R. S. (2015). Effect of different concentrations of coagulant, pressing time and dipping time on quality of buffalo colostrum paneer. Asian J. Dairy \& Food Res., 34 (1): 23-27.

Saleh, E. A.; Moussa, M. A. M.; R. M. Hassabo, R. M. and Ewis, A. M. (2019). Manufacturing functional stirred yoghurt supported by colostrum. J. Product. \& Dev., 24 (4): 945- 963.

Snedcor, G. W. and Cochran, W. G. (1967). Statistical Methods, $6^{\text {th }}$ ed., Iowa, U. S. A.

Soukoulis, C., Lyroni, E. and Tzia, C. (2010). Sensory profiling and hedonic judgment of probiotic ice cream as a function of hydrocolloids, yoghurt and milk fat content. LWT Food Sci. \&Techn. 43: 1351 .

Stelwagen, K.; Carpenter, E.; Haigh, B.; Hodgkinson, A. and T. Wheeler, T. (2009). Immune components of bovine colostrum and milk. J. Anim. Sci., 87:3-9.

Turgut, T. and Cakmacki, S. (2009). Investigation of possible use of probiotics in ice cream manufacture. Inter. J. of Dairy Techno., 62: 444. 
Tripathi, V. and Vashishtha, B. (2006). Bioactive compounds of colostrum and its application. Food Reviews Inter.,22 (3): 225-244.

Uruakpa, F.; Ismond, M. A. H. and Akobundu, E. N. T. (2002). Colostrum and its benefits: a review. Nutr Res., 22:755-767

Vineu, M.A.; Ahmadi, T. and Javad Ahmadi, J. (2005). Colostrum as nutritional supplement in sport. Agro alimentary Processes and Tech., XI (1): 33-40.

\section{استخدام اللبأ في تحسين الخواص الوظيفية و الكيميائية لتلأيس كريم الثواه الون}

امابل الشوادفى صالح - محمدعرفه موسى - رمضان مصطفى حسبو قسم بحوث كيمياء الالبان و *قدم بحوث تكنولوجيا الالبان - معهد بحوث الانتاج

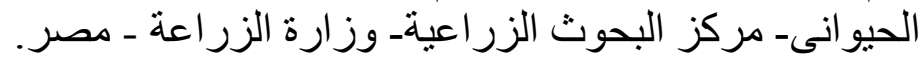

تم صناعة الايس كريم الوظيفى و المدعم بنسب مختلفة من اللبأ الجاموسى الفي ودر اسة الخصائص الوظيفية و الفيزيائية و الكيميائية و الحسية للائيس كريم الناتج.

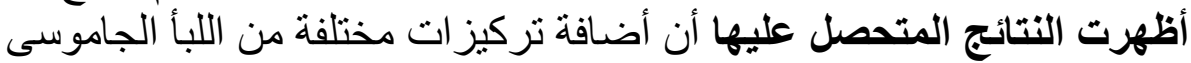

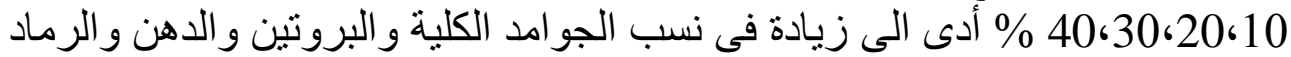

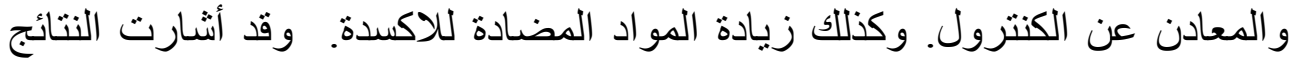

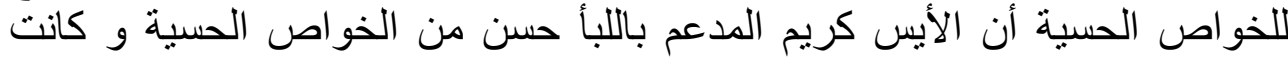

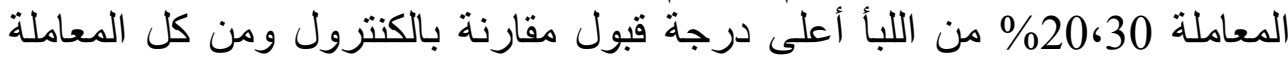
الأولى و الر ابعة. وزيادة محتوى الايس كريم الناتج من العناصر المعدنية.

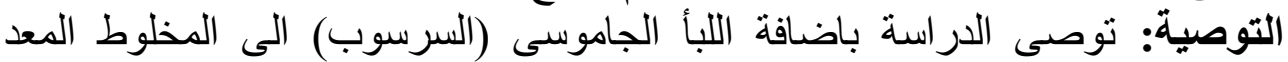
لصناعة الأيس كريم بنسب 20 أو 30\% وذللك لزيادة المو اد المضادة للاكسدة وتحسين الخواص الكيميائية و الخو اص الحسية للأيس كريم و كذاللك زيادة محتو اه من العناصر 